\title{
A new species of the genus Ectromopsis Antoine, 1949 from Turkey (Coleoptera: Tenebrionidae)
}

\author{
MaXim V. NABOZHenKo \\ Precaspian Institute of Biological Resources of the Daghestan Federal Research Centre \\ of the Russian Academy of Sciences, \\ M. Gadzhiev str., 45, 367000 Makhachkala, Republic of Dagestan, Russia \\ Dagestan State University, M. Gadzhiev str., 43a, 367000 Makhachkala, Republic of Dagestan, Russia \\ E-mail:nalassus@mail.ru
}

\begin{abstract}
Ectromopsis merkli sp. n. (Coleoptera: Tenebrionidae: Helopini) is described from Central Anatolia (coast of Eğirdir Lake). The species is the most similar to E. tantilla Ménétriés, 1848 from the Caspian depression (European Russia, West Kazakhstan) and differs in the body shape, structure of genae, the shape of pronotum and elytral punctation. Brief information about a relic type of distribution, trophic associations and adaptations of Ectromopsis spp. are given, as well as a key to species from the eastern part of the range. With seven figures.
\end{abstract}

Key words - Anatolia, Helopini, new species, Paratethys, supralittoral darkling beetles

\section{INTRODUCTION}

Ectromopsis Antoine, 1949 is a small genus of darkling beetles of the tribe Helopini (subtribe Cylindrinotina) with six species distributed on littoral sands mainly of continental waters: rivers and relict lakes, remains of the Neogene epycontinental basins of the Eastern Paratethys and the Mediterranean Sea (Nabozhenko 2005, 2011, ABDURA KHMANOv et al. 2016). The range of the genus Ectromopsis is fragmented: species occur very locally on sands of the Caspian lowland, in the Araks valley, on the sands near the Balkan and North African rivers; one species E. mendizabali Cobos, 1953 lives on the sea dunes of Spain.

Species of the genus Ectromopsis are morphologically intermediate between Nalassus Mulsant, 1854 and Xanthomus Mulsant, 1854. Species of the former genus occur mainly in forests and alpine meadows, sometimes steppes and subdeserts and they are trophically associated with foliose epiphytic (often Physciaceae), epilithic or epigeic (often Parmeliaceae) lichens (NABOZHENKo et al. 2016a, 2017). Species of Xanthomus inhabit marine sand 
dunes, having special morphological adaptations, such as translucent yellow body, long dense hairs on legs and fossorial or subfossorial protibiae (FERRER \& WhiteHeAd 2002), weakly developed subelytral cavity (Colombini $e t$ al. 1994; personal observations). Xanthomus are phyto-detritophagous beetles (LAGAR et al. 2016) and have well developed tarsi with large claws to move on herbaceous host plants (PONEL 1993). Species of the genus Ectromopsis have the same small and strongly convex body as Xanthomus and weakly developed subelytral cavity, but the colouration is dark brown and protibiae are not fossorial (as in Nalassus). Species of Ectromopsis are phytophagous and have similar mode of life as Xanthomus, feeding on herbaceous plants. They can be collected in mass with an entomological net at nightfall, as, for example, E. tantilla Ménétriés, 1849 (NABOZHENKo 2007).

The genus is not revised, but some important taxonomic works were published on species from Spain (Сово 1953), the Caucasus, Russia and Kazakhstan (IAblokoff-Khnzorian 1957, NABozhenko 2005), Bulgaria (ANGELOV \& MEDVEDEV 1981) and on the general taxonomy of the genus (Español \& Comas 1987). NABOzenKo et al. (2016) completed the diagnosis of Ectromopsis and allied genera. Below a new species of Ectromopsis is described from sand dunes of northern sands of Eğirdir Lake in Central Anatolia. The water fauna of this lake is relict and contains a series of Ponto-Caspian species (Wilke et al. 2007). Combination of conditions resemble those for E. tantilla, which also occurs in northern sandy areas around the Caspian Sea with rich relict Ponto-Caspian fauna (MoRduKhaI-Boltovskoi 1979).

\section{MATERIAL AND METHODS}

Beetles from the collection of Hungarian Natural History Museum, Budapest, Hungary (HNHM) kindly provided by Ottó Merkl were used. We used light microscope Micromed MC-4-Zoom LED with the camera ToupCam 14.0 MP for photographing details of structures. Photographs of beetles were made with Canon EOS 5D Mark IV Body, lens Canon MP-E65MM F2.8 Macro, flush bulb Canon Macro Twin Lite MT-26X-RT, stacking was made using Stack-shot 3X with enlarged macrorails s/n 3734; the photo system is installed on a reproduction machine Kaiser Copy Stand RS 1. Images were stacked in Helicon Focus 7.7.4 Pro. Photographs of Ectromopsis tantilla and E. bogatschevi are taken from the website "Beetles (Coleoptera) and coleopterists" (https://www.zin.ru/animalia/coleoptera/eng/index.html). 


\author{
RESULTS \\ ordo COLEOPTERA Linnaeus, 1758 \\ family TENEBRIONIDAE Latreille, 1802 \\ genus Ectromopsis Antoine, 1949
}

Type species: Catomus politicollis Allard, 1876

Ectromopsis merkli sp. n.

(Figs. 1-4)

Material - Holotype, $\widehat{\partial}(\mathrm{HNHM})$ and 5 paratypes ( $3 \circ$ in HNHM, $1 \delta^{\lambda}$ and 1 i in Zoological institute of the Russian Academy of Sciences, St Petersburg, Russia): "TURKIYE Prov. ISPARTA BOYALI", "Coast of Egirdir-gölü" 2001. 05. 24. Leg.: G. \& V. Rozner" [3804'44.74”N, 3050'52.56”E].

Description - Male. Body length $5 \mathrm{~mm}$, width $1.9 \mathrm{~mm}$. Body small, elongateoval, with lacquer shine, brown. Anterior margin of epistoma weakly rounded, epistomal angles slightly projected. Fine fronto-epistomal furrow present only on lateral sides of head. Lateral margin of head between gena and epistoma with strongly obtuse emargination. Outer margin of genae angle-shaped in basal third and straight in anterior two thirds. Head widest at eye level, where 1.28 times as wide as interocular space. Surface of head with weak impressions on sides, between gena and epistoma, but without fronto-epistomal transverse impression. Head dorsally with sparse (puncture diameter near 1.5 times as short as interpuncture space) and moderately coarse punctation of round punctures; ventrally with very coarse and dense punctation laterally and coarse transverse wrinkles medially from gula to prementum. Eyes small, convex, weakly oval; head without short ventral groove near eye. Antennae moderately long, with two apical antennomeres extending beyond base of pronotum. slightly thicker than in female, gradually widened to apex, medial antennomeres 3-8 simple, not strongly thickened. Ratio of length / width of 2-11 antennomeres: $2: 2.2,5: 2.4,4.2: 2.6$, 4: 2.6, 4: 2.6, 4: 2.6, 4: 2.6, 4: 2.8, 3.8: 3.1, 3.7: 3.2, 5:3.3.

Pronotum weakly transverse, widest in basal third (1.3 times as wide as long), 1.5 times as wide as head. Lateral margins weakly rounded, narrowed from base to anterior margin; anterior margin rounded, shorter than straight base; anterolateral angles not expressed, widely rounded, postero-lateral angles weakly obtuse. All margins beaded, except for middle of anterior margin; base with thicker bead than that of other margins. Disc of pronotum strongly transversely convex, with the same sparse and fine punctation as head dorsally. Prosternum coarsely and densely punctate, with several long setae. Prothoracic hypomera with irregular fine wrinkles and sparse fine setation. Prosternal process setose, weakly convex, not protruding. 

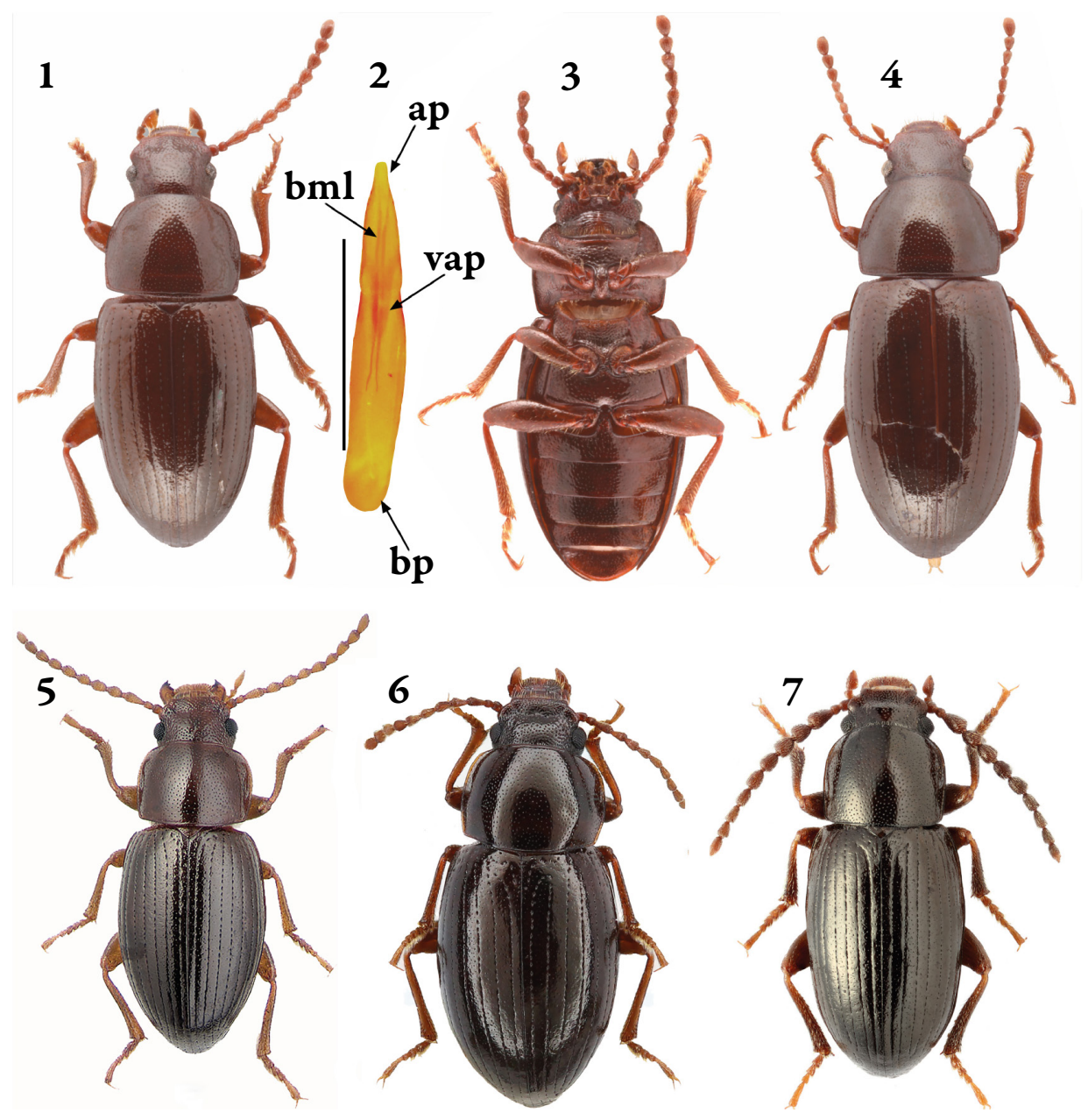

Figures 1-7. Ectromopsis imagines (for body measurements see the key in the main text): 1 =Ectromopsis merkli sp. n., male, holotype, dorsal view; 2 = aedeagus of $E$. merkli sp. n., ventrally (ap - apical piece, bp - basal piece, bml - baculi of median lobe, vap - ventral apophyses of apical lobe; scale bar $=0.5 \mathrm{~mm}$ ); $3=$ ditto, male, paratype, ventral view; $4=$ ditto, female, paratype, dorsal view; 5 = Ectromopsis tantilla Ménétriés, 1849, male, dorsal view (photo of K.V. Makarov); 6 = ditto, female (photo of S.V. Kolov); 7 = Ectromopsis bogatschevi Iablokoff-Khnzorian, 1957, male, dorsal view. (photo of K.V. Makarov)

Scutellar shield transverse, triangle, not punctate. Elytra 1.5 as long as wide, widest before middle, 1.8 times as wide as head, 1.2 times as wide and 2.38 times as long as pronotum. Striae consist of elongate separate punctures, which can be connected by fine furrows only at apex and on lateral sides; interstriae flat, 
very sparsely and finely punctate. Epipleura depressed at base. Mesoventrite, mesepimera, mes- and metepisperna with coarse and dense punctation; surface of mesoventrite with recumbent setation; metaventrite with sparse and fine punctation.

Legs moderately long. Trochanters and flexion side of femora (especially meso- and metafemora) with dense long yellowish hairs. Tibiae almost straight; protibiae slightly dorso-ventrally flattened in distal $2 / 3$, with projected outer anterior angle. Tarsi with dense brush of yellowish setae on plantar surface.

Abdominal ventrites sparsely and finely punctate; ventrite 1 with short recumbent setae; ventrite 5 completely beaded. Aedeagus typical for nalassoid Cylindrinotina (Fig. 2) (NABOZHENKo et al. 2016b).

Female. Body more robust. Antennae shorter and thinner, with one apical antennomere, extending beyond base of pronotum. Pronotum stronger narrowed to apical margin. Elytra widest at middle. Tarsi narrower than in male. Body length 5.2-5.6 $\mathrm{mm}$, width $2 \mathrm{~mm}$.

Etymology - The species is named in memory of my Hungarian colleague Ottó Merkl (1957-2021), great entomologist and friend, who made an invaluable contribution to entomology as a taxonomist, an editor of scientific journals, popularizer of entomology and the Hungarian Natural History Museum (SCHAWALleR 2021).

Diagnosis - The species is similar to E. tantilla (Figs. 5, 6) by the structure of antennae, but the shape of body is similar to those in E. bogatschevi (Fig. 7). See key below to distinguish the new species from other Ectromopsis on the east of the genus range.

Key to species of Ectromopsis from the eastern part of the range from the Eastern Mediterranean region to West Kazakhstan.

1(2). Anterior margin of epistoma widely emarginated, lateral margins of elytra weakly rounded, sometimes sub-parallel sided. Body length $4.8-5.6 \mathrm{~mm}$. Armenia (Fig. 7)

E. bogatschevi Iablokoff-Khnzorian, 1957

2(1). Anterior margin of epistoma straight or very weakly rounded, sometimes with projected angles.

3(4). Elytral interstriae weakly but distinctly convex; striae deep, punctures merged in entire deep furrows, only in the middle of anterior half punctures connected, but visible. Body length 5-5.2 mm. Bulgaria

E. bulgarica G.S. Medvedev \& Angelov, 1981

4(3). Elytral interstriae flat; striae consist of separate, not merged punctures on elytral disc and connected punctures or interrupted striae on sides and apical part.

5(6). Body length not exceeding $4 \mathrm{~mm}$; male antennomeres 4-8 strongly thickened, ball-shaped, with subequal length and width; elytra ball-shaped, strongly rounded on sides. Body length 3.4-3.6 mm. Greece E. ovipennis Allard, 1877

6(5). Body $4.5 \mathrm{~mm}$ and longer; male antennomeres 4-8 slightly thickened, elongate; elytra elongate-oval. 
7(8). Outer margin of genae evenly strongly rounded; anterior margin of pronotum completely beaded; pronotum not narrowed in apical quarter, width subequal at level of anterior and posterior angles; punctures in striae deep, oval, not dotted. Body more robust. Body length 4.5-5 mm. Russia, Kazakhstan (Caspian depression) (Figs. 5-6)

E. tantilla Ménétriés, 1849

8(7). Outer margin of genae angle-shaped in basal third and straight in anterior $1 / 3$; anterior margin of pronotum not beaded in middle; pronotum narrowed in apical quarter, shorter at level of anterior angles than at base; punctures in striae very fine, dotted. Body more elongate. Body length 5.2-5.6 mm. Turkey (coast of Eğirdir Lake) (Figs. 1-4)

E. merkli sp. n.

Acknowledgements - The author is much obliged to Ottó Merkl† (HNHM) for providing material, György Rozner (Balaton-felvidéki Nemzeti Park Igazgatóság, Csopak, Hungary) for coordinates of the type locality of the new species and the reviewer for valuable comments and corrections. The study was funded by the Russian Foundation for Basic Research and RPF (project no. 19-54-25001) and the basic research project of Precaspian Institute of Biological Resources of the Daghestan Federal Research Centre of the Russian Academy of Sciences, registration number AAAA-A17-117081640018-5.

\section{REFERENCES}

Abdurakhmanov G. M., Nabozhenko M. V., Abdurakhmanov A. G., Ivanushenko Yu. Yu. \& Daudova M. G. 2016: Geographic relations of darkling beetles (Coleoptera: Tenebrionidae) of the Palaearctic Tethys desert-steppe region with the historical review. South of Russia: ecology, development 11: 35-89. (in Russian) https://doi.org/10.18470/1992-1098-2016-3-35-89

Angelov P. A. \& Medvedev G. S. 1981: Tenebrionid beetles (Coleoptera, Tenebrionidae) of Bulgaria. - Entomologicheskoe Obozrenie 60: 302-315. (in Russian)

Совos A. 1953: Especies nuevas de coleópteros de la provincia de Almería, i. - Archivos del Instituto de Aclimatación (Almería) 1: 127-134.

Colombini I., Chelazzi L., Fallaci M. \& Palesse L. 1994: Zonation and surface activity of some Tenebrionid beetles living on a mediterranean sandy beach. - Journal of Arid Environments 28: 215-230. https://doi.org/10.1016/S0140-1963(05)80059-X

Español F. \& Comas J. 1987: Les espècies del gènere Gunarus Gozis, de la collecció del Museu de Zoologia de Barcelona (Col., Tenebrionidae, Helopinae). - Miscellània Zoològica 11: $165-171$. 
Ferrer J. \& Whitehead P. 2002: The genus Xanthomus Mulsant, 1854 (Coleoptera: Tenebrionidae), its evolutionary history and conservation significance. - Annales Zoologici 52: 383-401.

IABLOKoff-Khnzorian S. M. 1957: New species of Coleoptera from Armenian SSR and Nakhichevanian ASSR. - Zoologicheskiy Sbornik Akademii Nauk Armyanskoy SSR 3: 153-183. (in Russian)

Lagar M. C., Pazzagli L., Cappugi G., Giusfredi G., Colombini I., Fallaci M., Chelazzi L. \& ScApini F. 2016: Enzyme activity and trophic links of macroarthropods living on an exposed Mediterranean beach-dune system. - Italian Journal of Zoology 83: 221-232.

https://doi.org/10.1080/11250003.2016.1184331

Mordukhai-Boltovskoi P.D. 1979: Contribution and distribution of Caspian fauna in the light of modern data. Internationale Revue der gesamten Hydrobiologie und Hydrographie 64: $1-38$.

Nabozhenko M. V. 2005: Review of darkling beetles of the genus Ectromopsis Antoine, 1947 (Coleoptera, Tenebrionidae) of former USSR. - Caucasian Entomological Bulletin 1: 123 - 128. (in Russian) https://doi.org/10.23885/1814-3326-2005-1-2-123-128

Naвozhenko M. V. 2007: Landscape-biotopic distribution and trophic links of tenebrionid beetles of the tribe Helopini (Coleoptera, Tenebrionidae) in the Caucasus and PreCaucasus. - In: Matishov G.G. \& Lebedeva N.V. (eds): Studies of the Southern Scientific Centre of the Russian Academy of Sciences. Issue 3: Biodiversity and Transformation of Mountain Ecosystems of Caucasus. SSC RAS Publishing, Rostov-on-Don, pp. 242-252.

Naвоzнелко M. V. 2011: Darkling beetles of the genera Ectromopsis Allard, 1876 и Xanthomus Mulsant, 1854 (Coleoptera: Tenebrionidae) - representatives of supralittoral faunas of ancient and modern marine basins. - In: Kipyatkov V. E. \& Musolin D. L. (eds): Fundamental problems of entomology in $20^{\text {th }}$ Century. Materials of international scientific conference (16-20 May, 2011, St Petersburg). Saint Peterburg State University press, SaintPetersburg, p. 111. (in Russian)

Nabozhenko M. V., Keskin B., Dvadnenko K. D., Alpagut Keskin N. 2016a: The genus Gunarus Des Gozis, 1886 belongs to the subtribe Cylindrinotina (Coleoptera: Tenebrionidae: Helopini). - Caucasian Entomological Bulletin 12: 111-116.

https://doi.org/10.23885/1814-3326-2016-12-1-111-116

Nabozhenko M. V., Keskin B. \& Nabozhenko S. V. 2017: Life forms and strategies of lichenfeeding darkling beetles (Coleoptera, Tenebrionidae: Helopini). - Entomological Review 97: 735-746.

https://doi.org/10.1134/S0013873817060045

Nabozhenko M. V., LebedeVA N. V., Nabozhenko S. V. \& LebedeV V. D. 2016: The taxocene of lichen-feeding darkling Beetles (Coleoptera, Tenebrionidae: Helopini) in a forest-steppe ecotone. - Entomological Review 96: 101-113. https://doi.org/10.1134/S0013873816010115 
Nabozhenko M.V., Nikitsky N.B., Aalbu R. 2016b: Contributions to the knowledge of North American tenebrionids of the subtribe Cylindrinotina (Coleoptera: Tenebrionidae: Helopini). - Zootaxa 1: 155-164. https://doi.org/10.11646/zootaxa.4136.1.7

Ponel P. 1983: Contribution á la connaissance de la communauté des Arthropodes psammophiles de l'isthme de Giens. - Travaux Scientifiques Du Parc National De Port-Cros 9: 149-182.

SChawalleR W. 2021: In Memoriam: Dr. Ottó Merkl (1957-2021), Budapest. - Integrative Systematics 4: 1-2.

https://doi.org/10.18476/2021.302448

Wilke T., Albrecht C., Anistratenko V. V., Sahin S. K. \& Yildirim M. Z. 2007: Testing biogeographical hypotheses in space and time: faunal relationships of the putative ancient Lake Egirdir in Asia Minor. - Journal of Biogeography 34: 1807-1821.

https://doi.org/10.1111/j.1365-2699.2007.01727.x

\title{
Az Ectromopsis Antoine, 1949 gyászbogár génusz új faja Törökországból (Coleoptera: Tenebrionidae)
}

\author{
MAXim V. NABOZHenKo
}

Precaspian Institute of Biological Resources of the Daghestan Federal Research Centre of the Russian Academy of Sciences, M. Gadzhiev str., 45, 367000 Makhachkala, Republic of Dagestan, Russia Dagestan State University, M. Gadzhiev str., 43a, 367000 Makhachkala, Republic of Dagestan, Russia

E-mail:nalassus@mail.ru

Összefoglalás - Az Ectromopsis merkli sp.n. (Coleoptera: Tenebrionidae: Helopini) új gyászbogár faj kerül leírásra Közép-Anatóliából (Eğirdir-tó partja). Az új faj leginkább a Kaszpi-mélyföldön (Oroszország európai része, Nyugat-Kazahsztán) honos E. tantilla Ménétriés, 1849 fajhoz hasonlít. A két faj testfelépítésben, a pofalemez szerkezetében, az előtor alakjában és a szárnyfedő pontozottságában különbözik. Röviden ismertetésre kerül az Ectromopsis fajok reliktum típusú elterjedése, táplálkozási és alkalmazkodási körülményei, a génusz keleti felében elterjedt fajok felismerését határozákulcs segíti. Hét ábrával.

Kulcsszavak- Anatólia, Helopini, partmenti gyászbogarak, Paratethys, új faj 


\section{ÁBRAMAGYARÁZATOK}

1-7. ábra. Ectromopsis gyászbogár imágók (a testméreteket lásd a föszövegben olvasható határozókulcsban): 1 = Ectromopsis merkli sp. n., hím, holotípus, felülnézet; $2=$ E. merkli sp. n. aedeagus, alulnézet (ap - csúcsi rész, bp - bazális rész, bml - a középső lebeny nyúlványa, vap - a csúcstéri lebeny kinövése; méretléc $=0.5 \mathrm{~mm}$ ); $3=$ u. a., hím, paratípus, alulnézet; $4=$ u. a., nőstény, paratípus, felülnézet; $5=$ Ectromopsis tantilla Ménétriés, 1849, hím, felülnézet (fotó: K.V. Makarov); 6 = u. a., nőstény, (fotó: S.V. Kolov); 7 = Ectromopsis bogatschevi IablokoffKhnzorian, 1957, hím, felülnézet (fotó: K.V. Makarov). 